\title{
Persepsi petugas puskesmas, kader posyandu, serta akademisi di Kota Yogyakarta terhadap pedoman gizi seimbang (PGS) 2014
}

\author{
The perception of health center officers, cadres of posyandu, and academics about dietary guidelines \\ 2014 in Yogyakarta
}

Risma Saski Rahmita ${ }^{1}$, Yayi Suryo Prabandari², Siti Helmyati ${ }^{1}$

\begin{abstract}
Background: Based on the Basic Health Research on 2013, Indonesia is currently experiencing the global burden diseases. The prevalence of nutritional problems is higher than the limit of nutritional problems in the community, e.g. stunting $37.2 \%$, underweight $19.6 \%$, and overweight $11.9 \%$. This situation is quite alarming for the quality of Indonesian human resources. Therefore, guidelines for balanced nutrition that consists of 10 nutrition messages become important to solve. To know the readability of the guidelines in community, the perception of health center officers, cadres of posyandu, and academics to guidelines are needed.

Objectives: To explore the perception of health center officers, cadres of posyandu, and academics to guidelines for balanced nutrition 2014.

Methods: This research was a qualitative-based research with focus group discussions (FGD) methods. There were three different groups conducted in this research, e.g. health center officers, cadres of posyandu, and academics.

Results: There were some unclear messages to all groups, such as the words "many" and "enough" in the second message, "high protein" in the $3^{\text {rd }}$ message, "safe" and "enough" in the $7^{\text {th }}$ message, and "physical activity" in the $10^{\text {th }}$ message. From the picture of nutrition guidelines (nutrition pyramid), there was incompatibility between the nutrition pyramid and the guidelines for balanced nutrition 2014, especially in portions and the size of picture.

Conclusions: Guidelines for balanced nutrition 2014 had of been different percepted especially nutrition messages and the pyramid.
\end{abstract}

KEYWORDS: perception, guidelines for balanced nutrition 2014, nutrition pyramid

\begin{abstract}
ABSTRAK
Latar belakang: Berdasarkan riset kesehatan dasar (Riskesdas) 2013, Indonesia saat ini mengalami beban ganda masalah gizi. Prevalensi masalah gizi yang ada masih melebihi batas masalah gizi masyarakat: gizi kurang dan pendek 37,2\%, gizi kurang 19,6\%, dan gizi lebih 11,9\%. Keadaan ini cukup mengkhawatirkan bagi kualitas sumber daya manusia Indonesia. Oleh karena itu, diperlukan adanya upaya untuk memperbaiki keadaan ini dengan wujud mengeluarkan pedoman gizi seimbang (PGS) yang terdiri dari 10 pesan gizi yang telah disesuaikan oleh perkembangan permasalahan gizi di masyarakat. Untuk melihat keterbacaan pedoman gizi seimbang ini di masyarakat, perlu dilihat persepsi petugas puskesmas, kader posyandu, serta akademisi terhadap PGS 2014.

Tujuan: Mengeksplorasi persepsi petugas puskesmas, kader posyandu, serta akademisi terhadap PGS 2014.

Metode: Penelitian ini merupakan penelitian kualitatif dengan metode diskusi kelompok terarah (DKT) terhadap tiga kelompok berbeda, yaitu petugas puskesmas, kader posyandu, juga akademisi.
\end{abstract}

\footnotetext{
${ }^{1}$ Program Studi Gizi dan Kesehatan, Fakultas Kedokteran Universitas Gadjah Mada, JI Farmako, Sekip Utara, Yogyakarta, e-mail: jgdi.almaata@gmail.com

${ }^{2}$ Minat Perilaku dan Promosi Kesehatan, Fakultas Kedokteran UGM, JI Farmako, Sekip Utara, Yogyakarta
} 


\begin{abstract}
Hasil: Secara keseluruhan ada beberapa poin pesan yang dirasa kurang jelas untuk semua kelompok, seperti kata-kata "banyak" dan "cukup" pada pesan 2, "protein tinggi" pada pesan 3, "aman" dan "cukup" pada pesan 7, dan "aktivitas fisik" pada pesan 10. Untuk gambar pada tumpeng gizi seimbang (TGS), ada ketidaksesuaian antara tumpeng dengan PGS 2014, khususnya pada porsi dan ukuran gambarnya.

Kesimpulan: Sejauh ini, PGS 2014 masih memunculkan beragam persepsi terkait poin-poin pesan dan juga gambarnya.
\end{abstract}

KATA KUNCI: persepsi, pesan gizi seimbang (PGS) 2014, tumpeng gizi seimbang (TGS) 2014

\section{PENDAHULUAN}

Salah satu perilaku yang dapat mempengaruhi keadaan gizi dan kesehatan seseorang adalah kualitas dan kuantitas makanan yang dikonsumsi tiap individu. Namun demikian, seiring perkembangan zaman, pola konsumsi pangan di masyarakat menjadi kurang diperhatikan dan tidak sesuai dengan pesan gizi seimbang. Hasil penelitian Riskesdas 2013 menyatakan bahwa gambaran konsumsi buah dan sayur di Indonesia cenderung kurang ( $<5 \mathrm{porsi} /$ minggu). Sementara itu, pola konsumsi makanan berisiko manis di Indonesia sebesar $40,7 \%$ dan berlemak serta berkolesterol sebesar $40,7 \%$. Provinsi DIY memiliki proporsi yang tinggi untuk konsumsi makanan manis, yaitu $69 \%$ dan $50,7 \%$ untuk makanan berlemak dan berkolesterol (1). Hal ini diperkuat dengan hasil studi diet total di Provinsi DIY tahun 2014 yang ditemukan beberapa ketidakseimbangan konsumsi zat gizi, misalnya proporsi penduduk mengonsumsi gula, natrium, dan lemak melebihi pesan Permenkes No 30 tahun 2013 (2). Sementara berdasarkan hasil Riskesdas (2013) dapat diketahui kecenderungan peningkatan prevalensi gizi kurang, pendek, kurus, dan gemuk pada balita dari tahun 2007, 2010, dan 2013. Contohnya seperti masalah gizi kurang yang berada di kisaran angka 13 , yaitu $13 \%$ pada tahun $2007,13 \%$ pada tahun 2010 , dan meningkat ke $13,9 \%$ pada tahun 2013 . Selain itu, ada pula masalah stunting (pendek) pada balita sebanyak $18,8 \%$ pada tahun $2007,18,5 \%$ pada tahun 2010 , dan menurun ke $18 \%$ pada tahun 2010 . Hanya saja, masalah ini masih cukup serius dengan angka nasional $37,2 \%$, sedangkan masalah gizi lebih cukup fluktuatif, yaitu sebanyak $12,2 \%$ pada tahun $2007,14 \%$ pada tahun 2010 , dan menurun ke $11,9 \%$ pada tahun 2013 (1). Hal ini menandakan bahwa konsumsi masyarakat kurang sesuai dengan pesan gizi seimbang (PGS) yang telah dikeluarkan pemerintah yang bertujuan menyediakan pedoman makan dan berperilaku sehat bagi seluruh lapisan masyarakat berdasarkan prinsip konsumsi aneka ragam pangan, perilaku hidup bersih, aktivitas fisik, dan mempertahankan berat badan normal.

Untuk menjamin kualitas sumber daya manusia yang baik, berbagai negara sudah mulai mengimplementasikan ilmu gizi dalam wujud pesan gizi seimbang dengan ciri khas berbeda untuk masing-masing negara. Misalnya saja Cina yang menggunakan pagoda sebagai grafis pedoman makanannya, Jepang dengan spinning top-nya, Malaysia dengan piramidanya, Thailand dengan benderanya, Australia dengan bentuk lingkaran, USA dengan bentuk piring, dan Indonesia dengan bentuk tumpeng (3). Pada perkembangannya, Indonesia dahulu memiliki slogan empat sehat lima sempurna (ESLS) yang sangat melekat di benak masyarakat. Dengan adanya perkembangan masalah gizi di Indonesia, slogan ini dirasa sudah tidak mampu menjawab tantangan yang semakin beragam, sehingga pada tahun 1995 Departemen Kesehatan secara resmi mengeluarkan 13 pesan dasar gizi seimbang (Tabel 1). Dengan harapan mampu lebih menjangkau permasalahan yang ada, 13 pesan ini mulai disosialisasikan di masyarakat.

Pada penelitiannya yang berjudul "pengembangan pesan-pesan gizi seimbang dalam PUGS yang lebih praktis digunakan petugas gizi lapangan", Afriansyah menyatakan bahwa pesan-pesan dalam PUGS (Tabel 1) di Indonesia, sejak pertama dikeluarkan tahun 1995 belum ada tanda-tanda akan disesuaikan dengan temuan-temuan utama riset mutakhir yang berkembang di saat itu. Menurut pihak pengelola program (Direktorat Bina Gizi Masyarakat Depkes), operasionalisasi pesan 2-3-4 
dalam 13 PUGS sukar dilakukan oleh petugas gizi kesehatan, sehingga membingungkan ketika menghadapi masyarakat. Informasi mengenai kebingungan tersebut dikemukakan oleh para ahli gizi di daerah, sehingga ketepatan dan kepraktisan dari isi pesan dalam PUGS itu perlu dikaji ulang (4).

Pada perkembangannya, telah berlangsung serangkaian kegiatan ilmiah oleh Direktorat Bina Gizi Kementerian Kesehatan RI beserta beberapa pihak berupa workshop dan diskusi di Jakarta, Bandung, Yogyakarta, dan Bogor sebanyak 6 kali dalam waktu dua bulan pada tahun 2013 hingga booklet "Pesan Gizi Seimbang" dapat diselesaikan (5). Tidak hanya itu, kajian ilmiah juga sudah dituangkan ke dalam naskah akademik yang disiapkan oleh tim penyusun dengan melakukan kajian secara mendalam terhadap: perkembangan masalah gizi, 13 pesan dasar pedoman umum gizi seimbang (PUGS) tahun 2003 dan penggunaannya di lapangan, pengalaman di berbagai negara dalam pengembangan pedoman gizi seimbang, serta pembahasan melalui Widya Karya Pangan dan Gizi XI (3). Pada tanggal 27 Januari 2014 juga diadakan workshop para pakar pemerintah serta non-pemerintah, lintas sektor, lintas program, dan organisasi profesi dan yang menghasilkn sepuluh PGS baru dengan revisi di beberapa bagian. Telah diterbitkan pula peraturan yang tertuang dalam Peraturan Menteri Kesehatan Republik Indonesia Nomor 41 Tahun 2014 tentang pedoman gizi seimbang (6).

Dengan membandingkan kedua periode pedoman gizi (Tabel 1), tampak adanya pengurangan, penambahan, serta perubahan redaksi dari pedoman gizi yang lama menuju pedoman gizi yang baru. Inti pesan yang masih sama di antara keduanya yaitu: "aneka ragam makanan", "sumber karbohidrat berubah menjadi makanan pokok", "makan pagi berubah menjadi sarapan", "minum air bersih, cukup, aman berubah menjadi minum air putih cukup, aman", "aktivitas fisik dan olah raga berubah menjadi aktivitas fisik", dan "label di kemasan pangan". Pesan yang dihilangkan adalah pesan terkait "jumlah karbohidrat maupun lemak yang harus dikonsumsi", "jenis garam", "minuman beralkohol", dan "konsumsi makanan sehat" yang sebenarnya bisa diterapkan di masyarakat umum, dan pesan "sumber zat besi", "ASI-MP ASI" yang dirasa hanya menyasar ke golongan umur tertentu saja. Tambahan pada pedoman gizi terbaru adalah untuk poin "syukuri dan nikmati", "sayur dan buah", "lauk protein tinggi", "batasi pangan manis, asin, berlemak", "cuci tangan dengan air bersih mengalir", dan "pantau berat badan normal".

Tabel 1. Perbandingan 13 PUGS dan PGS 2014

\begin{tabular}{|c|c|c|}
\hline $\begin{array}{c}\text { Pesan } \\
\text { ke- }\end{array}$ & 13 PUGS & PGS 2014 \\
\hline 1 & Makanlah aneka ragam makanan & Syukuri dan nikmati anekaragam makanan \\
\hline 2 & $\begin{array}{l}\text { Makanlah makanan untuk memenuhi kecukupan } \\
\text { energi }\end{array}$ & Banyak makan sayuran dan cukup buah-buahan \\
\hline 3 & $\begin{array}{l}\text { Makanlah makanan sumber karbohidrat setengah } \\
\text { dari kebutuhan energi }\end{array}$ & $\begin{array}{l}\text { Biasakan mengonsumsi lauk pauk yang mengandung } \\
\text { protein tinggi }\end{array}$ \\
\hline 4 & $\begin{array}{l}\text { Batasi konsumsi lemak dan minyak sampai } \\
\text { seperempat dari kecukupan energi }\end{array}$ & $\begin{array}{l}\text { Biasakan mengonsumsi aneka ragam makanan } \\
\text { pokok }\end{array}$ \\
\hline 5 & Gunakan garam beriodium & Batasi konsumsi pangan manis, asin dan berlemak \\
\hline 6 & Makanlah makanan sumber zat besi & Biasakan sarapan \\
\hline 7 & $\begin{array}{l}\text { Berikan ASI saja pada bayi sampai umur } 6 \text { bulan } \\
\text { dan tambahkan MP-ASI sesudahnya }\end{array}$ & Biasakan minum air putih yang cukup dan aman \\
\hline 8 & Biasakan makan pagi & Biasakan membaca label pada kemasan pangan \\
\hline 9 & Minumlah air bersih, aman yang cukup jumlahnya & Cuci tangan pakai sabun dengan air bersih mengalir \\
\hline 10 & Lakukan kegiatan fisik dan olahraga secara teratur & $\begin{array}{l}\text { Lakukan aktivitas fisik yang cukup dan pertahankan } \\
\text { berat badan normal }\end{array}$ \\
\hline 11 & Hindari minum minuman beralkohol & \\
\hline 12 & Makanlah makanan yang aman bagi kesehatan & \\
\hline 13 & Bacalah label pada makanan yang dikemas & \\
\hline
\end{tabular}


Setelah mengetahui perkembangan pesan gizi di Indonesia beserta perubahannya dari waktu ke waktu, perlu diadakan penilaian keterbacaan dari pesan tersebut melalui persepsi informan untuk mengetahui pesan gizi dapat diterima atau tidak oleh masyarakat. Menurut Sarwono, penginderaan dapat digunakan sebagai alat mengumpulkan informasi (7). Seorang individu pada akhirnya dapat memunculkan persepsi setelah mendapatkan rangsang indera, baik dari dalam diri maupun luar diri (8). Dalam hal ini yang menjadi objek adalah dirinya sendiri. Dalam kehidupan sehari-hari, sikap, pendidikan (pengetahuan), lingkungan, serta budaya menjadi faktor penting untuk menciptakan persepsi dalam diri seseorang. Persepsi masyarakat akan beragam sesuai lingkungan tempat bersosialisasi dan juga akses terhadap informasi mengenai pesan gizi seimbang (9).

Dalam berkomunikasi, pesan disampaikan menggunakan suatu media oleh pengirim kepada penerima pesan. Pesan ini akan disampaikan dengan baik apabila komunikasi dari kedua belah pihak diorganisasikan secara baik dan jelas. Mengingat penyampai pesan gizi seimbang kepada masyarakat di lapangan adalah petugas puskesmas, kader posyandu, serta guru SMP (akademisi) yang memiliki peran sangat penting, penelitian ini bermaksud melihat persepsi masyarakat yang diwakili oleh petugas puskesmas, kader posyandu, serta akademisi di Kota Yogyakarta dalam memahami PGS yang baru dengan harapan bisa menggali informasi dan pemikiran masyarakat secara mendalam.

\section{BAHAN DAN METODE}

Penelitian ini adalah jenis penelitian kualitatif yang berfokus pada fenomena sosial dan persepsi serta perasaan dari partisipan penelitian (10). Pada penelitian ini dilakukan penggalian informasi serta pemahaman dari sebuah masalah atau isu untuk mendapat gambaran detail suatu masalah dari informan (11). Dengan melakukan pendekatan ini, ingin diketahui persepsi yang dimiliki oleh petugas puskesmas, kader posyandu, dan akademisi di Kota Yogyakarta terhadap PGS 2014.
Penelitian ini dilakukan di Daerah Istimewa Yogyakarta tepatnya di wilayah Kota Yogyakarta pada bulan April-Desember tahun 2014. Diskusi kelompok terarah (DKT) dilakukan di Gedung Bioetik Fakultas Kedokteran UGM pada hari berbeda. Teknik sampling yang digunakan pada penelitian ini adalah purposive sampling yaitu pemilihan sampel dilakukan dengan tujuan tertentu (10). Rubin menambahkan bahwa dengan menggunakan teknik purposive sampling, pemilihan informan mengikuti kriteria yang diinginkan peneliti, antara lain: memiliki pengetahuan terkait budaya maupun situasi pada area yang akan diteliti yaitu pesan kesehatan, mau untuk berbicara/bercerita, dan merupakan representatif dari kelompok yang diinginkan sesuai tujuan penelitian agar didapat data yang bisa menjelaskan masalah yang terjadi (12). Pada penelitian ini jumlah sampel tidak ditentukan terlebih dahulu, namun disesuaikan dengan variasi kelompok yang dikehendaki agar didapatkan variasi data. Kriteria inklusi adalah petugas puskesmas, kader posyandu, serta guru, bertugas di Kota Yogyakarta, bersedia menjadi partisipan penelitian dengan menandatangani informed consent. Kriteria eksklusi adalah partisipan yang pernah mengikuti DKT tentang PUGS pada penelitian serupa.

Pada penelitian ini dipilih tiga puskesmas yang lokasinya dekat dengan Universitas Gadjah Mada setelah mendapatkan daftar puskesmas dari Dinas Kesehatan Kota Yogyakarta. Tiga petugas puskesmas diundang dari masing-masing puskesmas terpilih. Tidak ada kriteria khusus peserta yang hadir karena setiap orang yang bertugas di puskesmas memiliki hak untuk menyampaikan informasi kesehatan kepada pengunjung puskesmas. Peserta yang hadir beragam, antara lain: dokter, perawat, bidan, promosi kesehatan, dan ahli gizi. Dari tiga puskesmas yang sudah terpilih didapatkan rekomendasi kader yang masih bertugas di wilayah masing-masing puskesmas, serta masih aktif mengikuti kegiatan ataupun penugasan yang diberikan oleh pihak puskesmas. Guru yang ada di Kota Yogyakarta dipilih dari tiga SMP yang terdiri dari SMP negeri dan swasta, juga guru dari tiga SMA yang terdiri dari SMA negeri dan swasta. Pada akhirnya guru SMA tidak dilibatkan dalam DKT karena kendala dalam menyesuaikan 
jadwal masing-masing instansi. Selama pengambilan data, hanya ada satu orang yang hadir sehingga DKT dianggap gagal dan dibatalkan.

Data dikumpulkan dengan menerapkan metode DKT dengan bantuan instrumen panduan DKT. Panduan teknis DKT berisi tata urutan proses mulai dari pembuka oleh fasilitator, perkenalan diri peserta, ijin untuk mendokumentasikan seluruh jalannya DKT termasuk penandatanganan informed consent, penjelasan aturan main, kemudian proses DKT, perangkuman, dan diakhiri dengan penutup oleh fasilitator. Beberapa pertanyaan dalam proses DKT antara lain megenai kepahaman, kejelasan, daya persuasi dan kemenarikan, serta sasaran pesan. Selain itu, ada pula instrumen formulir persetujuan dari partisipan, alat perekam, serta catatan lapangan untuk menerjemahkan bentuk audio ke dalam bentuk verbatim. Sebelum digunakan, alat perekam yang digunakan dipastikan fungsinya terlebih dahulu.

Data yang dikumpulkan adalah data primer dan data sekunder. Data primer didapatkan melalui DKT yang dilakukan kepada tiga kelompok partisipan yang terdiri dari kelompok petugas puskesmas, kader posyandu, serta guru dengan panduan DKT. Metode DKT berlangsung dengan mengangkat isu keterbacaan pesan dalam PGS 2014. Hasil DKT ini akan baik bila terdiri atas partisipan dengan karakteristik dan kepentingan yang serupa (13). Data sekunder yang digunakan merupakan data dari Dinas Kesehatan Kota Yogyakarta, rekomendasi puskesmas, serta sekolah terpilih.

Analisis data menggunakan Microsoft Excel dan Microsoft Word secara manual dan dilakukan sesuai dengan proses menurut Matthew dan Huberman (14) meliputi aktivitas pengumpulan data, reduksi data, penyajian data, dan penarikan/ verifikasi kesimpulan. Pada penelitian ini, tahapan analisis data yang dilakukan meliputi: mendengarkan hasil rekaman dari hasil DKT, menerjemahkan dan menyusun transkrip dari hasil DKT, membuat kategori data sesuai topik, membaca ulang semua hasil DKT sehingga didapat gambaran, dan menyusun kesimpulan.

Penelitian ini menggunakan thick description untuk menangkap kompleksitas dan keunikan informasi kasus secara utuh (10). Thick description didapat dengan merekam dan mencatat semua hasil DKT.

Penelitian dilakukan dengan mendapatkan izin dan ethical clearance dari Komisi Etik Penelitian Kedokteran dan Kesehatan Fakultas Kedokteran Universitas Gadjah Mada nomor KE/FK/698/EC. Pengambilan data partisipan dilakukan setelah penjelasan mengenai kegiatan penelitian kepada partisipan serta mendapatkan kembali informed consent yang sudah ditandatangani sebagai tanda bahwa partisipan bersedia berpartisipasi dalam kegiatan penelitian.

\section{HASIL}

\section{Karakteristik partisipan}

Pengambilan data dilakukan dengan cara DKT untuk mengetahui persepsi masing-masing kelompok terhadap PGS 2014. Penelitian ini melibatkan 20 informan. Karakteristik semua partisipan penelitian dapat dilihat dalam Tabel 2.

Tabel 2. Karakteristik partisipan penelitian

\begin{tabular}{llc}
\hline & Karakteristik & DKT (orang) \\
\hline \multirow{2}{*}{ Jenis kelamin } & Laki-laki & 6 \\
& Perempuan & 14 \\
\multirow{3}{*}{ Pekerjaan } & Guru SMP & 7 \\
& Petugas puskesmas & 8 \\
& Kader posyandu & 5 \\
Usia & $21-30$ & 4 \\
(tahun) & $31-40$ & 3 \\
& $41-50$ & 12 \\
& $51-60$ & 1 \\
\hline
\end{tabular}

Tingkat kehadiran informan untuk masingmasing DKT berdasarkan undangan yang telah disebarkan yaitu: petugas puskesmas sebesar $88,8 \%$ (8 dari 9 orang), kader posyandu sebesar $55,5 \%$ (5 dari 9 orang), guru SMP sebesar $77,7 \%$ (7 dari 9 orang), dan guru SMA sebesar 8,3\% (1 dari 12 orang). DKT pada guru SMA dianggap gagal sehingga ditiadakan.

\section{Pemahaman guru SMP, petugas puskesmas, dan kader posyandu terhadap PGS 2014}

Pesan nomor 1 mengenai "syukuri dan nikmati aneka ragam pangan" dapat disimpulkan dari ketiga 
kelompok informan bahwa pesan tersebut dapat dipahami oleh ketiga kelompok. Namun demikian, persepsi yang didapatkan berbeda-beda. Pada guru SMP kata aneka ragam dipersepsikan sebagai bahan makanan alamiah dan instan, Menurut informan petugas puskesmas berpersepsi tidak hanya jenisnya yang beragam, namun juga kandungan gizi di dalamnya. Ada pula persepsi aneka ragam yaitu tidak hanya makanan pokok namun juga jajanan.

Pesan nomor 2 mengenai "banyak makan sayur dan cukup buah" didapatkan kesimpulan bahwa pesan tersebut dapat dipahami oleh semua informan. Namun, ada satu informan yang kurang paham mengenai pernyataan "banyak dan cukup" karena tidak ada ukuran yang jelas.

Ditinjau dari pemahaman pembaca mengenai pesan nomor 3 "biasakan mengonsumsi lauk-pauk yang mengandung protein tinggi" dapat disimpulkan bahwa terjadi kebingungan yang dimaksud dengan "protein tinggi". Ada yang berpersepsi protein yang kelasnya tinggi atau protein yang kandungannya tinggi. Pesan tersebut masih menimbulkan banyak persepsi.

Pesan nomor 4 mengenai "biasakan mengonsumsi aneka ragam makanan pokok" cenderung lebih mudah dipahami, namun ada beberapa pernyataan informan yang menyebutkan bahwa pesan tersebut dirasa tidak perlu diulang karena telah mencakup pesan yang ada di nomor satu. Informan lain menyebutkan mampu memahami makna pesan yang tertera pada nomor 4, namun merasa menerapkan karena mayoritas makanan pokok penduduk Indonesia adalah nasi yang bahan bakunya adalah beras. Pesan nomor 5 mengenai "batasi konsumsi pangan manis, asin, dan berlemak" telah dipahami oleh ketiga kelompok informan.

Pesan nomor 6 mengenai "biasakan sarapan" telah dapat dipahami oleh ketiga kelompok informan. Pada pesan nomor 7 "biasakan minum air putih yang cukup dan aman" dirasa masih belum dipahami karena kata "cukup" bersifat kualitatif yang tidak bisa diukur masih menimbulkan pertanyaan dikarenakan belum adanya informasi mengenai kriteria air yang aman dikonsumsi.

Pada pesan nomor 8 "biasakan membaca label pada kemasan pangan" telah dipahami oleh ketiga kelompok. Namun demikian, ada informan yang masih kurang paham mengenai yang dimaksud pembacaan label yaitu pada tanggal kadaluarsa saja atau meliputi informasi label yang lain mengenai kandungan gizi, izin BPOM, kehalalan, dan sebagainya.

Pada pesan nomor 9 "cuci tangan pakai sabun dengan air mengalir" dapat dipahami oleh ketiga kelompok informan. "Lakukan aktivitas fisik yang cukup dan pertahankan berat badan normal" merupakan pesan ke 10. Pesan tersebut dapat dipahami oleh ketiga kelompok namun pada informan petugas puskesmas timbul banyak pertanyaan pada kata "aktivitas fisik" yang menimbulkan banyak persepsi. Aktivitas yang dimaksud pada pesan tersebut adalah aktivitas fisik biasa yang dilakukan sehari-hari atau yang bersifat teratur dan terukur.

\section{Kejelasan dan kemenarikan pesan menurut guru SMP, petugas puskesmas, dan kader posyandu terhadap PGS 2014}

Ditinjau dari kejelasan dan kemenarikan pesan nomor 1 mengenai "syukuri dan nikmati aneka ragam pangan", dapat disimpulkan dari ketiga kelompok informan bahwa pesan tersebut bersifat jelas dan menarik. Ada berbagai alasan yang muncul mengenai kejelasan dan kemenarikan pesan seperti pada kata "syukuri" membangun sebuah asumsi bahwa masyarakat harus nrimo tanpa perlu adanya perbaikan gizi. Ada pula yang mengartikan kata "nikmati" yang masih membingungkan karena kata "nikmati" di masyarakat tergantung pada kepuasan masing-masing orang. Informan lain memberi jawaban yang berbeda mengenai pesan ini bahwa kata "syukuri" sudah jelas yang artinya kita harus senantiasa bersyukur pada Tuhan dengan memakan makanan yang satu dan tidak menelantarkan makanan yang lain.

Mengenai pesan kedua dirasa sudah jelas, namun dari ketiga kelompok informan kata "banyak" dapat diartikan salah yaitu boleh dikonsumsi sebanyak-banyaknya. Informan petugas puskesmas memberikan saran agar kalimat ditambah dengan kalimat "sesuai kebutuhan" karena ada pula yang berpantang pada jenis sayur dan buah tertentu. Informan kader menambahkan bahwa isi pesan 
harus diberi ukuran yang jelas misalnya saja besar porsi sayur dan buah yang harus dikonsumsi.

Pesan nomor 3 mengenai "biasakan mengonsumsi lauk-pauk yang mengandung protein tinggi" dirasa kurang jelas oleh ketiga kelompok informan. Misalnya terjadi beberapa persepsi seperti kata protein tinggi yang cenderung mengacu pada bahan makanan daging-dagingan (hewani) tidak ada unsur nabati dan protein tinggi biasanya digunakan pada pasien pasca operasi. Seharusnya diberi macam protein yaitu protein hewani dan protein nabati. Salah seorang informan merasa pesan tersebut menarik karena kata "mengandung" yang artinya tidak hanya harus makan namun juga dipilih untuk mengonsumsi makanan yang bergizi.

Pesan nomor 4 dirasa sudah jelas, namun kata "makanan pokok" dirasa kurang jelas karena makanan pokok dapat diasumsikan makanan belum jadi. Selain itu, makanan pokok yang lazim dikonsumsi masyarakat Indonesia hanya beras (nasi) dan makanan selain nasi termasuk makanan selingan.

Pesan nomor 5 mengenai "batasi konsumsi pangan manis, asin, dan berlemak" dirasa kurang jelas. Informan guru SMP menyatakan untuk penggantian kata "pangan" diubah menjadi "makanan" karena kata pangan seperti orang Jawa menganggap penggunaanya kurang halus. Ada pula yang menyatakan kurang jelas terhadap kata "berlemak" yang terkesan hanya yang bersumber dari makanan hewani seperti gajih.

Pesan nomor 6 "biasakan sarapan pagi" sudah menarik dan jelas. Pesan nomor 7 dirasa masih belum jelas pada beberapa bagian. Seperti halnya kata "cukup" belum diketahui pasti jumlah yang dibutuhkan dalam waktu satu hari. Kata "aman" dirasa cukup menarik karena telah mengarahkan masyarakat supaya lebih berhati-hati dalam memilih air yang akan dikonsumsi. Namun demikian, belum ada kriteria penilaian mengenai air yang aman dikonsumsi.

Pesan nomor 8 dirasa sudah cukup jelas dan menarik tentang pembacaan label pada kemasan pangan. Namun demikian, berdasarkan pengamatan oleh ketiga kelompok di lapangan menyatakan bahwa hal tersebut masih jarang dilakukan. Biasanya masyarakat akan "melek" terhadap suatu informasi jika sudah muncul tren kasus/berita.

Pesan nomor 9 mengenai cuci tangan menggunakan sabun sudah jelas dan menarik. Ada beberapa usulan seperti sebaiknya dicantumkan langkah-langkah mencuci tangan yang benar.

Pesan nomor 10 mengenai "Lakukan aktivitas fisik yang cukup dan pertahankan berat badan normal". Pesan tersebut dapat dirasa kurang jelas oleh ketiga kelompok. Ketidakjelasan terletak pada kata "aktivitas fisik" yang menimbulkan banyak persepsi. Aktivitas yang dimaksud pada pesan tersebut apakah aktivitas fisik rumah tangga atau olah raga. Menurut informan petugas puskesmas perlu dilakukan penjelasan lebih lanjut terutama mengenai strengthness dan endurance dengan waktu 150 menit per minggu untuk menjaga berat badan normal.

\section{Daya persuasi pesan menurut guru SMP, petugas puskesmas, dan kader posyandu terhadap PGS 2014}

Menurut informan guru SMP dan petugas puskesmas pesan nomor 1 sudah cukup memiliki makna ajakan. Namun demikian, ada infoman yang memiliki pandangan berbeda bahwa pesan tersebut belum memiliki daya persuasi tinggi karena hanya merupakan rutinitas yang dilakukan belum cukup memancing masyarakat untuk segera dilakukan.

Pesan nomor 2 mengenai banyak makan sayur dan cukup buah dirasa sudah memiliki daya persuasi yang tinggi mengingat masih banyak anak yang tidak suka terhadap sayur dan buah.

Pesan nomor 3 mengenai membiasakan mengonsumsi lauk pauk yang mengandung protein tinggi. Menurut ketiga kelompok informan pesan tersebut sudah memiliki daya persuasi atau mengajak masyarakat. Namun demikian, perlu adanya pendampingan informasi mengenai kata "tinggi protein" agar masyarakat lebih jelas.

Menurut informasi yang didapat dari informan, pesan nomor 4 telah memiliki daya persuasi membujuk atau mengajak. Pada salah satu informan mengusulkan untuk mengganti kata "biasakan" menjadi "biasakanlah" agar ada penekanan dalam pesan tersebut. 
Menurut informan pesan nomor 5 dan 6 mengenai "batasi konsumsi pangan manis, asin, dan berlemak" serta "biasakan sarapan" sudah sangat membujuk. Salah seorang informan menyatakan pesan ini dirasa sudah baik dan mengajak masyarakat terutama anak sekolah agar membiasakan sarapan sebelum beraktivitas. Namun demikian, untuk pesan nomor 5 perlu adanya pendampingan agar informasi yang diterima masyarakat lebih jelas.

Pesan nomor 7 telah memiliki daya persuasi menurut tiga kelompok informan, begitu pula dengan pesan ke 8,9 dan 10. Namun demikian, keempat pesan tersebut perlu pendampingan dan penjelasan lebih lanjut agar masyarakat dapat memahami dan melakukan dengan benar.

Ketepatan sasaran pesan menurut guru SMP, petugas puskesmas, dan kader posyandu terhadap PGS 2014

Berdasarkan hasil informasi yang didapat dari ketiga kelompok informan mengenai pesan dalam PGS 2014 didapatkan bahwa semua pesan dapat diterima oleh masyarakat dari semua golongan sehat. Namun demikian, pada pesan nomor 8 mengenai pembacaan label pada kemasan pada kata "membaca" tidak dapat diterapkan pada orang tua yang tidak jelas penglihatannya dan tuna netra.
Gambar tumpeng gizi seimbang (TGS) 2014 menurut guru SMP, petugas puskesmas, dan kader posyandu

Menurut guru SMP, gambar pada TGS (Gambar 1) dirasa cukup mudah dipahami. Informan juga menilai gambar yang dirasa sudah bagus. Pada gambar, aktivitas fisik ternyata sudah beragam antara lain menyapu dan olah raga. Namun demikian, ada kejanggalan dalam TGS itu sendiri. Pada TGS porsi lauk-pauk setara dengan makanan pokok, namun porsi justru ditunjukkan dengan ukuran gambar yang berbeda. Dari segi warna sudah menarik karena perpaduan warna yang cukup kontras antara daun yang hijau dengan komposisi di atasnya yang berwarna kuning dan ungu.

Menurut informan petugas kesehatan secara umum, gambar sudah menarik, namun tidak semua pesan PGS tertuang dalam gambar. Misalnya, untuk pesan 1) mensyukuri, 6) sarapan, dan 8) label makanan. Ada tanggapan untuk gambar sepak bola pada gambar terkesan olah raga yang agak ngoyo. Muncul usulan gambar untuk sarapan adalah gambar jam menyerupai piring yang menunjuk ke arah pukul tujuh disertai gambar sendoknya, sedangkan pesan label bisa ditambahkan gambar label makanan dan mensyukuri bisa berupa gambar orang yang

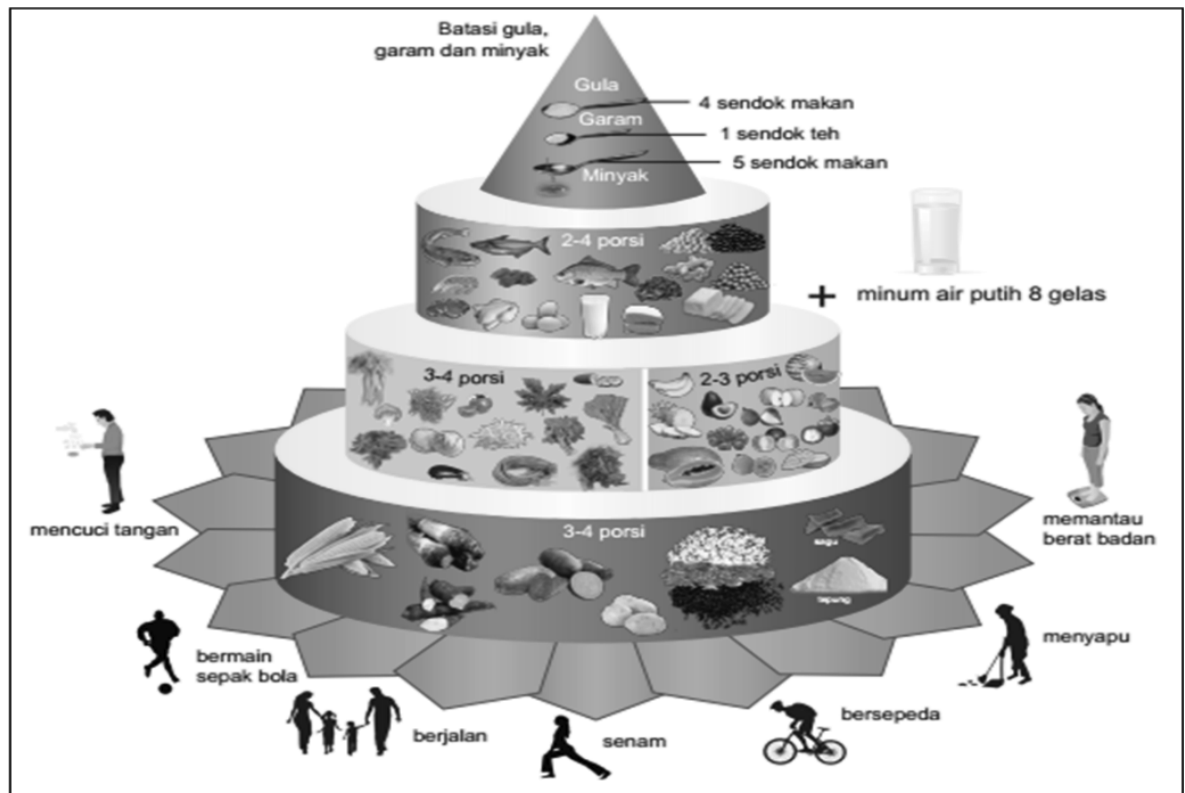

Gambar 1. Tumpeng gizi seimbang (TGS) 
menengadahkan tangannya menyerupai berdo'a. Ketidaksesuaian dijumpai lagi pada sayuran dan buah-buahan pada riskesdas yang disarankan sebanyak 3-5 porsi, di PGS kurang spesifik namun sayur "banyak" dan buah "cukup". Pada gambar terlihat bahwa sayuran justru setara dengan makanan pokok, sedangkan lauk pauk setara dengan buah. Untuk bentuknya yang mengerucut sudah dapat dipahami oleh petugas kesehatan bahwa semakin ke atas semakin minimal.

Sedangkan menurut informan kader posyandu, ketidaksesuaian antara angka dengan gambar ditemukan dalam TGS. Pada angka disebutkan 3-4 porsi untuk sayur dan makanan pokok, namun pada gambar ukurannya berbeda (seharusnya sama banyak). Saat dibndingkan, pada PGS ada kata-kata "banyak sayur", namun pada gambar yang banyak justru sumber karbohidratnya. Namun demikian, ditinjau dari segi warna dan gambar, bisa dibilang TGS ini cukup menarik.

\section{BAHASAN}

Hasil penelitian ini tidak dapat digunakan untuk generalisasi persepsi semua petugas puskesmas, kader posyandu, serta akademisi terhadap PGS 2014 di kota lain. Dilihat dari segi kejelasan pesan, beberapa kelompok menilai ada ketidakjelasan pada pesan nomor 3 untuk kata "protein tinggi" dan pesan nomor 7 untuk kata "aman" dan "cukup" yang menimbulkan banyak persepsi, tergantung orang yang membaca, tingkat ekonomi pembaca, dan tingkat kehausan pembaca. Hal ini sejalan dengan Robbins (15) yang menyebutkan bahwa situasi merupakan salah satu faktor yang mempengaruhi terbentuknya persepsi seseorang.

Adanya beberapa penilaian daya persuasi atau daya bujuk pada beberapa poin pesan ini sejalan dengan Hartati (16) yang menyebutkan bahwa secara implisit, beberapa pesan mengandung argumen yang dapat mempengaruhi perubahan sikap seseorang setelah mendapat pesan. Keberhasilan perubahan sikap melalui pesan yang persuasif sangat tergantung dari tinggi/rendahnya kebutuhan seseorang untuk mencerna informasi secara cermat dan mendalam.
Gambar pada TGS dirasa cukup mudah dipahami karena seperti piramida makanan pada pelajaran biologi. Semakin ke atas, porsi yang dimakan semakin sedikit. Ukuran dari tiap bagian piramida menunjukkan jumlah porsi setiap hari yang dianjurkan untuk dikonsumsi (17).

Pada poin pesan nomor 2 ada usulan untuk menambah jumlah keterangan porsi konsumsi sayur dan buah mengingat kebiasaan orang Indonesia untuk mengonsumsi sayur dan buah masih sangat kurang. Hal ini sejalan dengan Gallagher (18) yang menyatakan bahwa salah satu pertimbangan dalam mendesain strategi komunikasi kesehatan yang efektif adalah dengan memberitahu perilaku kesehatan yang sebenarnya direkomendasikan dan outcome yang diharapkan nantinya juga dapat tertuang dalam pesan tersebut.

Munculnya beragam persepsi untuk bahasan yang sama pada tiga kelompok di atas disebabkan oleh beberapa faktor, antara lain: karakteristik pribadi dari pembuat persepsi (sikap, kepribadian, motif, minat, pengalaman masa lalu, dan harapan-harapan seseorang), objek atau target yang diartikan (PGS 2014 yang masih baru), serta situasi saat persepsi itu dibuat (waktu, tempat, dan keadaan sosial) dari partisipan (15).

\section{KESIMPULAN DAN SARAN}

Persepsi petugas puskesmas, kader posyandu, dan akademisi di Kota Yogyakarta dalam memahami PGS 2014 cukup beragam. Namun demikian, telah diakui terdapat ketidakjelasan yang hampir sama pada beberapa poin pesan, seperti "banyak" dan "cukup" pada pesan 2, "protein tinggi" pada pesan 3, "aman" dan "cukup" pada pesan 7, dan "aktivitas fisik" pada pesan 10. Pada gambar TGS, dari segi bentuk maupun warna sudah dirasa menarik dan mudah dipahami. Namun demikian, ada ketidaksesuaian ukuran porsi yang dianjurkan dengan ukuran pada gambar, yaitu 3-4 porsi pada makanan pokok dan sayur.

Ada beberapa kritik dan saran yang disampaikan petugas puskesmas, kader posyandu, dan akademisi di Kota Yogyakarta mengenai PGS 2014 ini, di antaranya: kurang gencarnya promosi 
di masyarakat, masih panjangnya pesan dan dirasa kurang aplikatif, serta kurang jelasnya beberapa kata sehingga memunculkan banyak persepsi, kemudian muncul usulan untuk menyederhanakan pesan tersebut. Beberapa partisipan menghendaki juga untuk membuat buku saku atau definisi operasional agar pembaca memiliki persepsi yang sama tentang pesan gizi tersebut.

Bagi pemerintah, sebaiknya pesan gizi yang telah terbentuk ini tidak langsung diganti demi memenuhi permintaan masyarakat yang tidak paham. Hal ini diperkuat dengan pengaturan pedoman dalam Permenkes nomor 41 tahun 2014 (15). Upaya sosialisasi atau promosi di masyarakat diharapkan dapat meningkatkan pemahaman mengenai PGS dan gambar TGS, baik melalui penyuluhan, poster, lomba cipta karya, buku panduan, maupun iklan layanan masyarakat yang dimunculkan di berbagai media untuk memanfaatkan pula media-media yang saat ini tidak bisa dilepaskan dari kehidupan sosial masyarakat.

Bagi peneliti lain tinjauan besarnya perubahan persepsi masyarakat mengenai PGS 2014 ini setelah beberapa waktu berlalu sejak diluncurkannya pesan ini, bisa dua, tiga, atau beberapa tahun ke depan dapat dilakukan. Hal ini dapat digunakan juga untuk mengevaluasi peran media yang telah dimanfaatkan untuk menyebarkan informasi gizi. Penelitian kuantitatif yang dilakukan dalam penelitian payung bersama dengan penelitian ini juga menilai keterbacaan pesan dalam PGS 2014 dengan beberapa sasaran: anak SD, SMP, SMA, serta mahasiswa/i di Kota Yogyakarta. Terkait penelitian kualitatif, sampel yang lebih bervariasi dapat memberikan persepsi yang lebih kaya ke depannya.

\section{RUJUKAN}

1. Kementerian Kesehatan Republik Indonesia. Riset kesehatan dasar 2013. Jakarta: Badan Penelitian dan Pengembangan Kesehatan RI;

2. Sugianto, Faozan M, Setyani A. Buku studi diet total survei konsumsi makanan individu Daerah Istimewa Yogyakarta 2014. Jakarta: Badan Penelitian dan Pengembangan Kesehatan RI; 2014.
3. Kementerian Kesehatan RI. Naskah akademik pedoman gizi seimbang (PGS) 2013. Jakarta: Direktorat Jenderal Bina Gizi dan KIA Kementerian Kesehatan RI;

4. Afriansyah, Nurfi, Mudjianto, Trintrin T, Hidayat, Tjetjep S, et al. Pengembangan pesan-pesan gizi seimbang dalam PUGS yang lebih praktis digunakan petugas gizi lapangan. J PGM. 2003;26(2):35-41.

5. Kementerian Kesehatan Republik Indonesia. Usulan konsep pesan umum dan pesan khusus gizi seimbang beserta penjelasannya. Jakarta: Badan Penelitian dan Pengembangan Kesehatan Kementerian Kesehatan Rl;

6. Menteri Kesehatan Republik Indonesia. Peraturan Menteri Kesehatan Republik Indonesia nomor 41 tahun 2014 tentang pedoman gizi seimbang. Jakarta: Kementerian Kesehatan Republik Indonesia; 2014.

7. Sarwono S. Pengantar psikologi umum. Jakarta: Rajawali Press; 2009.

8. Sunaryo. Psikologi untuk keperawatan. Jakarta: EGC; 2004.

9. Rakhmat J. Metode penelitian komunikasi. Bandung: PT. Remaja Rosdakarya; 2001.

10. Lodico M, Spaulding D, Voegtle K. Methods in educational research theory to practice. USA: Joseph-Bass, A Willey Imprint; 2006.

11. Creswell J. Research design: qualitative inquiry and research design: choosing among five tradition third edition. London: SAGE Publication; 2013.

12. Engel, Rafael J, Schutt, Russel K. Fundamentals of social work research. USA: SAGE Publication; 2010.

13. Rietbergen, Jennifer, Narayan, McCracken D. Participation and social assessment tools and technique. USA: The World Bank; 1998.

14. Sudarma M. Sosiologi untuk kesehatan. Jakarta: Salemba Medika; 2008.

15. Robbins, P S, Timothy A, Judge. Organizational behavior, 12th ed. Jakarta: Salemba Empat; 2008.

16. Hartati S. Effects of argument quality, need for cognition and issue involvement to the attitude 
toward a message given through persuasive communication. J Psikol. 2005;32(2):92100.

17. Depkes RI. PUGS (panduan umum untuk petugas). Jakarta: Direktorat Jendral Bina Kesehatan Masyarakat; 2003.
18. Gallagher KM, Updegraff JA. Health message framing effects on attitudes, intentions, and behavior: a meta-analytic review. Ann Behav Med [Internet]. 2012 Feb 13;43(1):101-16. Available from: http://link.springer.com/10.1007/ s12160-011-9308-7 